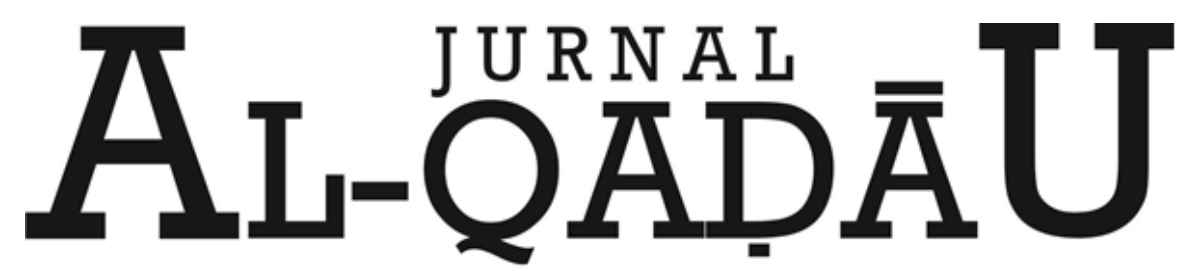

PERADILAN dan HUKUM KELUARGA ISLAM

\title{
Tinjauan Yuridis Terhadap Kekuatan Akta Perseroan Terbatas Terhadap Notaris Pemegang Saham
}

Judicial review of the legal standing of the limited company Deed towards Shareholders Notary

Muhammad Anis

Dosen Fakultas syariah dan hukum UIN Alauddin Makassar

Email : muhammadanis1966@gmail.com

\begin{tabular}{|c|c|}
\hline $\begin{array}{c}\text { Info } \\
\text { Artikel }\end{array}$ & Abstract \\
\hline $\begin{array}{l}\text { Diterima } \\
17 \\
\text { Februari } \\
2017 \\
\\
\text { Revisi I } \\
09 \\
\text { Maret } \\
2017 \\
\\
\text { Revisi II } \\
05 \\
\text { April } \\
\text { 2017 }\end{array}$ & $\begin{array}{l}\text { Perseroan terbatas merupakan bentuk usaha ekonomi yang } \\
\text { pertanggungjawabannya bersifat terbatas dan juga memberikan } \\
\text { kemudahan bagi pemegang saham untuk mengalihkan sahamnya. Dalam } \\
\text { pendirian perseroan terbatas masyarakat memilih Akta Notaris karena } \\
\text { tidak ada pejabat lain selain Notaris yang ditunjuk oleh pemerintah untuk } \\
\text { membuat Akta Pendirian Perseroan Terbatas dan berkekuatan hukum } \\
\text { pasti. Namun Notaris yang membuat Akta mempunyai kedudukan dalam } \\
\text { Perseroan Terbatas maka kekuatan hukum suatu akta pendirian } \\
\text { perseroan terbatas (PT) sebagai pengurus serta pemegang saham dalam } \\
\text { sebuah perseroan terbatas (PT) maka akta Notaris tersebut hanya } \\
\text { mempunyai kekuatan hukum sebagai akta dibawah tangan. Adanya } \\
\text { kesadaran bagi para Notaris agar kiranya memperhatikan prosedur } \\
\text { pembuatan suatu akta pendirian perseroan terbatas (PT) sekaligus } \\
\text { mengetahui akibat-akibathukum yang ditimbulkan. } \\
\text { Kata Kunci : Perseroan Terbatas }\end{array}$ \\
\hline $\begin{array}{l}\text { Disetujui } \\
23 \\
\text { Mei } \\
2017\end{array}$ & $\begin{array}{l}\text { Limited company is a form of economic enterprise is limited } \\
\text { accountability and also makes it easy for shareholders to transfer their } \\
\text { shares. In the creation of the public limited company chose Deed because } \\
\text { no other officers other than the Notary appointed by the government to } \\
\text { make the Deed of Establishment of a Limited Liability Company and is } \\
\text { legally bound. But notaries who made the deed has no place in the Limited } \\
\text { Liability legal force of a deed of incorporation of a limited liability } \\
\text { company (PT) as a board member and shareholder in a limited liability } \\
\text { company (PT), the notary deed is only a legal effect as a deed under hand. } \\
\text { The awareness from the Notary is to pay attention to the procedures of a } \\
\text { deed of incorporation of a limited liability company (PT) while } \\
\text { recognizing the legal consequences arising. } \\
\text { Keywords: Limited Company }\end{array}$ \\
\hline
\end{tabular}




\section{PENDAHULUAN}

\section{A. Latar Belakang}

Perseroan terbatas merupakan bentuk usaha kegiatan ekonomi yang paling diminati saat ini, disamping karena pertanggungjawabannya yang bersifat terbatas juga memberikan kemudahan bagi pemiliknya (pemegang saham) untuk mengalihkan sahamnya (kepada pihak lain) dengan menjual seluruh saham yang dimilikinya pada perusahaa tersebut.

Wirjono Prodjodikoro menyatakan bahwa dalam praktek ada dua macam Perseroan Terbatas, yaitu yang bersifat tertutup, artinya tanggung jawab terbatas pada beberapa orang saja (private companies). Macam yang lain bersifat terbuka, yaitu disediakan untuk khalayak ramai tak terbatas. ${ }^{1}$

Pengertian Perseroan Terbatas menurut pasal 1 undang-undang No 1 Tahun 1995 menyatakahn bahwa perseroan terbatas yang selanjutnya disebut Perseroan adalah badan hukum yang didirikan berdasarkan perjanjian melakukan kegiatan usaha dengan modal besar yang seluruhnya terbagi dalam saham, dan memenuhi persyaratan yang ditetapkan dalam undang-undang serta peraturan pelaksanaannya. ${ }^{2}$

Kenyataan sebelum berlakunya Undang-undang No 1 tahun 1995 adalah :

a. Tidak ditentukan berapa besarnya modal dasar, modal ditempakan dan modal disetor.

b. Tidak ada jangka waktu pengesahan

c. Bentuk Akta Pendirian dibuat sesuai selera Notaris karena belum ada format baku;

d. Pengurus tidak jelas

Kenyataan sesudah berlakunya Undang-undang No 1 Tahun 1995 adalah :

Modal dasar paling sedikit Rp. 20.000.000,- (dua puluh juta rupiah), modal ditempatkan paling seditik $25 \%$ dari modal dasar sedangkan modal disetor paling sedikit $50 \%$ dari modal ditempatkan.

a. Jangka waktu pengesahan paling lama 60 (enam puluh) hari setelah permohonan diterima;

\footnotetext{
${ }^{1}$ Soedikno Mertokusumo, Hukum Acara Perdata Indonesia (Yokyakarta: Liberty, 1998), h. 75

${ }^{2}$ HR.Otje Salman S dan anton F. Susanti, Teori hukum (Bandung: Refika aditama, 2004), h. 251
} 
b. Sudah ada bentuk Akta Pendirian format baku yang dikeluarkan oleh Menteri Hukum dan HAM

c. Nama-nama Pengurus tercantum jelas pada Akta Pendirian.

Salah satu persyaratan yang ditetapkan dalam UUPT adalah Perseroan Terbatas didirikan oleh 2 (dua) orang atau lebih dengan Akta Notaris yang dibuat dalam bahasa Indonesia. Perjanjian Pendirian Perseroan Terbatas yang dilakukan oleh para pendiri tersebut dituangkan dalam satu Akta Notaris yang disebut dengan Akta Pendirian. Rumus Pasal 8 ayat (1) UUPT menyatakan bahwa Akta Pendirian Perseroan Terbatas memuat Anggaran Dasar Perseroan Terbatas. ${ }^{3}$ secara keseluruhan dan berbagai keterangan lainnya yang diperlukan, seperti :

a. Identitas para pendiri perseroan terbatas;

b. Identitas para Pengurus Direksi, Pengawas, komisaris Perseroan Terbatas;

c. Keterangan mengenai para pemegang saham yang telah mengambil bagian saham atau nilai yang diperjanjikan dari saham yang telah disempatkan disetor pada saat pendirian.

Tugas Notaris adalah membuat Akta, menyimpan dan menerbitkan salinan (grosse). Notaris juga mengkonstatir apa yang terjadi dan apa yang dilihat dan dialami serta mencatatnya dalam Akta. Adapun wewenang utama Notaris adalah membuat Akta Otentik. Menurut G.H.S. Luban Tobing bahwa syarat-syarat yang harus dipenuhi untuk dapat menjadi Akta Otentik adalah :

a. Akta itu harus dibuat oleh dan dihadapan seorang pejabat umum;

b. Akta itu harus dibuat dalam bentuk yang ditentunkan dalam UU;

c. Pejabat umum atau oleh siapa Akta itu dibuat harus mempunyai wewenang untuk Akta itu.

Alasan masyarakat memilih Akta Notaris dalam pendirian perseroan Terbatas adalah :

a. Karena tidak ada pejabat lain selain Notaris yang ditunjuk oleh pemerintah untuk membuat Akta Pendirian Perseroan Terbatas.

b. Berkekuatan hukum pasti.

\footnotetext{
${ }^{3}$ G.H.S. Luban , Peraturan Jabatan Notaris, h. 48
} 
Peranan Notaris dalam pendirian Perseroan Terbatas adalah ikut membantu proses kelahiran suatu Perseroan Terbatas Notaris mensyaratkan 3 (tiga) nama untuk diperiksa ke Departemen Hukum dan HAM karena Perseroan Terbatas di seluruh dunia tidak boleh ada yang sama. ${ }^{4}$

Notaris meminta slip setoran sebagai bukti bahwa modal disetor telah masuk ke rekening tabungan perseroan tersebut serta menerbitkan Salinan Akta Pendirian. Setelah Akta Pendirian ditanda tangani oleh para pihak maka Perseroan Terbatas telah dapat menjalankan kegiatan usaha, namun dilihat dari segi yuridisnya Perseroan Terbatas tersebut belum dapat dikategorikan sebagai badan hukum dengan alas an Akta Pendirian Perseroan Terbatas itu belum mempunyai kekuatan hukum. Sehingga pada kesempatan ini penulis mengadakan penelitian secara normative dengan memfokuskan pada fakta berkaitan dengan yang menentukan kekuatan hukum Akta Pendirian suatu Perseroan Terbatas. Demikian pula kekuatan hukum Akta Pendirian Perseroan Terbatas jika Notaris di satu pihak atas nama pribadi mempunyai kedudukan di dalam Perseroan Terbatas dan di pihak lain justru Notaris itu membuat Akta Pendirian Perseroan Terbatas tersebut. ${ }^{5}$

\section{B. Rumusan Masalah}

Berdasarkan latar belakag di atas, maka rumusan masalah sebagai berikut :

1. Sejauh manakah kekuatan hukum sebuah Akta Pendirian Perseroan Terbatas?

2. Apakah akibat hukum yang timbul bilamana Notaris yang membuat Akta mempunyai kedudukan dalam Perseroan Terbatas?

\section{Tujuan dan Kegunaan}

1. Tujuan

a. Untuk mengetahui dan menganalisis kekuatan hukum, sebuah Akta Pendirian Perseroan Terbatas.

b. Untuk mengetahui akibat hukum apa yang timbul bilamana Notaris yang membuat Akta mempunyai kedudukan dalam Perseroan Terbatas tersebut.

2. Kegunaan

${ }^{4}$ Suhrawardi K. Lubis, Etika Profesi Hukum (Jakarta: Sinar Grafika, 2002), h. 41

${ }^{5}$ R. Soebekti dan R. Tjitrosudibio, Kitab undang-undang Hukum Perdata (Jakarta: PT. Pradnya paramita 2005), h. 174 
Kegunaan penelitian yang diharapkan adalah sebagai berikut :

a. Dapat menjadi bahan pertimbangan bagi para Notaris dalam pembuatan Akta Pendirian Perseroan Terbatas.

b. Dapat menjadi sumber informasi bagi masyarakat yang hendak mendirikan Perseroan Terbatas maupun pihak ketiga yang ingin berhubungan dengan Perseroan Terbatas tersebut.

\section{TINJAUAN PUSTAKA}

\section{A. Pengertian Akta}

Akta adalah suatu tulisan yang ditandatangani dan sengaja dibuat untuk digunakan sebagai bukti bahwa telah dilakukan suatu perbuatan hukum tertentu. Berikut ini diberikan pengertian Akta menurut beberapa ahli, yaitu :

a. R. Subekti, Akta ialah suatu tulisan yang memang dengan sengaja dibuat untuk dijadikan bukti tentang suatu peristiwa dan ditandatangani.

b. Setiawan, Akta ialah suatu tulisan yang sengaja dibuat untuk membuktikan suatu peristiwa atau hubungan hukum tertentu.

c. Sudikno Mertokusumo, Akta adalah surat yang diberi tanda tangan yang memuat peristiwa yang menjadi dasar suatu hak atau perikatan yang dibuat sejak semula dengan sengaja untuk pembuktian. ${ }^{6}$

Bukti tertulis bisa berupa Akta di bawah Tangan atau akta Otentik. Menurut Sudikno Mertokusumo, Akta di bawah tangan ialah Akta yang sengaja dibuat untuk pembuktian oleh para pihak tanpa bantuan dari seorang pejabat. Jadi Akta dibawah Tangan ialah Akta yang dibuat oleh pihak-pihak yang berkepentingan. Akta di bawah Tangan tidak dibuat oleh atau dihadapan pejabat yang berwenang.

Pengertian akta Otentik terdapat pada Pasal 1868 KUHPerdata yang berbunyi "Suatu akta Otentik ialah Akta yang di dalam bentuk yang ditentukan oleh Undangundang, dibuat oleh atau dihadapan pegawai-pegawai umum yang berkuasa untuk itu di tempat dimana Akta tersebut dibuatnya. ${ }^{7}$

\footnotetext{
${ }^{6}$ Sudikno Mertokusumo, Hukum Acara Perdata Indonesia, h. 128

${ }^{7}$ G.H.S. Lumban Tobing, Peraturan Jabatan Notaris, h. 51
} 
Sudikno Mertokusumo, mengemukakan Akta Otentik adalah Akta yang dibuat oleh pejabat yang diberi wewenang untuk itu oleh penguasa menurut ketentuanketentuan yang telah ditetapkan, baik dengan maupun tanpa bantuan dari yang berkepentingan, yang mencatat apa yang dimintakan untuk dimuat di dalamnya oleh yang berkepentingan. Jadi Akta Otentik adalah Akta yang dibuat oleh atau dihadapan pejabat yang berwenang menurut ketentuan yang ditetapkan oleh Undang-undang. Pejabat yang dimaksud antara lain ialah Notaris, Panitera, Jurusita, Pegawai Catatan Sipil, Hakim dan sebagainya.

Akta Notaris ialah Suatu akta Otentik karena Akta itu dibuat oleh atau dihadapan Notaris sebagai pejabat. Dari segi isinya menurut G.H.S. Lumban Tobing menyatakan bahwa ada Akta Notaris yang merupakan Akta pihak dan ada pula Akta Notaris yang merupakan Akta Pejabat.

Menurut Setiawan (1992 : 404), dari segi bentuknya kita mengenal Akta yang dibuat dalam bentuk minit. Minit atau Asli Akta ini disimpan di Kantor Notaris, sedangkan turunannya diberikan kepada para pihak. Dan sagi bentuknya, kita mengenal pula Akta Notaris yang dibuat serta diberikan dalam bentuk originalnya.

\section{B. Fungsi dan Kedudukan Akta Notaris}

Sudikno Mertokusumo (1998 : 129), menguraikan akta dapat mempunyai fungsi formil sebagai alat bukti. Akta berfungsi formil berarti bahwa untuk lengkapnya atau sempurnanya (bukan untuk sahnya) suatu perbuatan hukum, haruslah dibuat suatu Akta. Disini Akta merupakan syarat formil untuk adanya suatu perbuatan hukum. ${ }^{8}$

Selanjutnya penulis mengemukakan kekuatan pembuktian dari alat bukti tulisan menurut G.H.S. Lumban Tobing (1992 : 54), bahwa kekuatan pembuktian Akta Otentik, dengan demikian juga Akta Notaris adalah akibat langsung yang merupakan keharusan dari ketentuan perundang-undangan, bahwa harus ada Akta Otentik sebagai alat pembuktian dan dari tugas yang dibebankan oleh undang-undang kepada pejabat atau orang-orang tertentu.

Dalam pasal 1870 KUHPerdata mengemukakan bahwa suatu memberikan diantara para pihak beserta ahli waris-ahli warisnya atau orang-orang yang mendapat hak dari mereka, suatu bukti yang sempurna tentang apa yang dimuat di dalamnya.

\footnotetext{
${ }^{8}$ Soedikno Mertokusumo, Hukum Acara Perdata Indonesia, h. 61
} 
Dengan kata lain Akta Otentik bertujuan untuk dapat digunakan sebagai alat bukti bagi para pihak. Sempurna yang dimaksud dalam pasal ini memuat pengertian bahwa Akta Otentik merupakan alat pembuktian yang mengikat dan lengkap. Mengikat dalam arti apa yang tercantum dalam Akta tersebut harus dipercaya oleh Hakim sebagai sesuatu yang benar selama tidak dibuktikan sebaliknya. Jadi beban pembuktian ini jatuh kepada pihak lawan. Pihak lawan misalnya dapat mengemukakan bahwa perjanjian tersebut tidak berlaku lagi. Perlawanan ini dapat melumpuhkan si pemegang Akta Otentik apabila dapat dibuktikan Pada Akta Otentik dengan demikian juga pada Akta Notaris dikenal 3 (tiga) jenis kekuat an pembuktian, yaitu :

\section{Kekuatan Pembuktian Lahir Akta Otentik}

Kekuatan pembuktian lahiriah ini dimaksudkan kemampuan dari Akta itu sendiri untuk membuktikan dirinya sebagai Akta Otentik. mengemukakan bahwa membuktikan tidak saja antara pihak yang bersangkutan, tetapi juga terdapat pihak ketiga. Bahwa pada tanggal tersebut dalam Akta kedua belah pihak tersebut sudah menghadap di muka pegawa umum (Notaris) dan menerangkan apa yang ditulis dalam Akta tersebut. ${ }^{9}$

Menurut Sudikno Mertokusumo menyatakan sebagai asas berlaku acta publica probant seseipsa, yang berarti bahwa sesuatu Akta yang lahirnya tampak sebagai Akta Otentik serta memenuhi syarat-syarat yang telah ditentukan, maka Akta itu berlaku atau dapat dianggap sebagai Akta Otentik sampai terbukti sebaliknya. ${ }^{10}$

\section{Kekuatan Pembuktian Formil Akta Otentik}

Dengan kekuatan pembuktian formil ini oleh Akta Otentik dibuktikan, bahwa pejabat yang bersangkutan telah menyatakan dalam tulisan itu, sebagaimana yang tercantum dalam Akta itu dan selain dari itu kebenaran dari apa yang diuraikan oleh pejabat dalam Akta itu sebagai yang dilakukan dan disaksikannya di dalam menjalankan jabatannya itu.

R. Subekti, mengatakan tentang kekuatan pembuktian formil Akta Otentik bahwa membuktikan kepada para pihak, bahwa mereka sudah menerangkan apa yang dituliskan dalam Akta tersebut (kekuatan pembuktian formil). Sedangkan menurut

\footnotetext{
${ }^{9}$ R. Soebekti, Aneka Perjanjian, h. 72

${ }^{10}$ R. Soebekti, Aneka Perjanjian, h. 30
} 
Sudikno Mertokusumo, dalam arti formil Akta Otentik membuktikan kebenaran daripada apa yang dilihat, didengar dan dilakukan pejabat. Dalam hal ini yang pasti ialah tentang tanggal dan tempat Akta dibuat serta keaslian tanda tangan. ${ }^{11}$

\section{Kekuatan Pembuktian Materil Akta Otentik}

Antara para pihak yang bersangkutan dan para ahli waris serta penerima hak mereka, Akta memberikan pembuktian yang lengkap tentang kebenaran dari apa yang tercantum dalam Akta itu dengan pengecualian dari apa yang tercantum di dalamnya sebagai suatu pemberitahuan belaka dan yang tidak mempunyai hubungan langsung dengan yang menjadi pokok dalam Akta itu.

Sudikno Mertokusumo (1998 : 131) mengemukakan bahwa Akta pejabat tidak lain hanya untuk membuktikan kebenaran apa yang dilihat dan dilakukan oleh pejabat, kebenaran dari pernyataan pejabat serta bahwa Akta itu dibuat oleh pejabat adalah pasti bagi siapapun.

Lanjut dijelaskan Sudikno Mertokusumo (1998 : 132-133) tentang kekuatan pembuktian Akta di bawah tangan adalah :

a. Kekuatan Pembuktian Lahir Akta di bawah Tangan

Oleh karena tanda tangan pada Akta di bawah Tangan kemungkinannya masih dapat dipungkiri, maka Akte di bawah Tangan ini tidak mempunyai kekuatan pembuktian lahir. Kalau tanda tangan pada Akta di bawah Tangan itu diakui oleh yang bersangkutan, maka Akta itu merupakan bukti sempurna yang berlaku terhadap para pihak yang bersangkutan.

b. Kekuatan Pembuktian Formil Akta di bawah Tangan

Kekuatan pembuktian formil dari Akta di bawah Tangan ini sama dengan kekuatan formil dari Akta Otentik. Jadi disini telah pasti bagi siapapun bahwa di penandatanganan menyatakan seperti yang terdapat di atas tanda tangannya.

c. Kekuatan Pembuktian Materil Akta di bahwa Tangan

Suatu Akta di bawah tangan hanyalah memberikan pembuktian sempurna demi keuntungan orang kepada siapa si penandatangan hendak memberikan bukti, terhadap setiap orang lainnya kekuatan pembuktiannya adalah bebas.

\footnotetext{
${ }^{11}$ R. Soebekti, Aneka Perjanjian, h. 131
} 
Apabila Akta Pendirian Perseroan Terbatas tidak dibuat oleh Notaris atau dibuat oleh Notaris tetapi tidak menggunakan bahasa Indonesia, maka akibatnya adalah Akta Pendirian Perseroan Terbatas tidak disahkan atau ditolak pengesahannya oleh Menteri Hukum dan HAM. Dengan adanya Akta yang demikian ini maka pendirian Perseroan Terbatas tersebut tidak sah. Artinya kedudukan Akta Notaris disini merupakan syarat mutlak terjadinya suatu perseroan, disamping sebagai alat bukti bahwa suatu Perseroan Terbatas telah berdiri. ${ }^{12}$

\section{Dasar Hukum Pendirian Perseroan Terbatas}

Ketentuan perundang-undangan yang mengatur mengenai Perseroan Terbatas saat ini terdapat pada Undang-undang No. 3 Tahun 1982 tentang wajib Daftar Perusahaan dan Undang-undang No 1 tahun 1995 tentang Perseroan Terbatas yang menggantikan berlakunya Buku I Bab III pasal 36 sampai dengan pasal 56 KUHDagang (Wetboek van Koop Handel, Staatsbald, 1847 :23) sebagaimana telah diubah terkahir dengan UU No. 4 Tahun 1971 (per tanggal 7 Maret 1996) dan Ordonansi Maskapai Andil Indonesia (Ordonantie op de Indonesische Maatschaapij op Aan Deelen - IMA stb 1939 sampai 569 jo).

Keadaan sebelum berlakunya Undang-undang No. 1 Tahun 1995 tersebut menyebabkan terjadinya dualisme Undang-undang yang mengatur persoalan. Hal ini memang dikehendaki oleh pemerintah Kolonial Belanda waktu itu yang membedakan golongan penduduk dan hukum yang berlaku bagi mereka. Bagi golongan Eropa atau yang dipersamakan dengan itu berlaku pasal 35/26 KUHDagang. Sedangkan bagi golongan bumiputera berlaku ketentuan Ordonansi maskapai Andil Indonesia. Kelemahan peraturan tentang Perseroan Terbatas dalam KUHDagang adalah jumlah kaidahnya yang sangat terbatas (hanya 21 pasal), sedangkan kelemahan IMA adalah sifatnya yang diskriminatif yaitu hanya berlaku untuk WNI pribumi.

\section{Syarat-syarat Pendirian Perseroan Terbatas}

Anisitus Amanat (1995/1997 : 21-22) menyajikan beberapa persyaratan untuk mendirikan Perseroan Terbatas menurut UUPT :

a. Didirikan atas dasar perjanjian dengan jumlah pendiri minimal 2 (dua) orang (pasal

\footnotetext{
${ }^{12}$ Anisitus Amanat, Pembahasan Undang-Undang perseroan terbatas dan penerapannya dalam akta Notaris (Jakarta: PT Raja Grafindo persada, 1997), h. 159
} 
1 jo pasal 7);

b. Akta Pendirian harus dibuat oleh Notaris dengan menggunakan bahasan Indonesia (Pasal 7);

c. Jumlah nilai nominal modal dasar minimal Rp. 20.000.000,- (dua puluh juta) (Pasal $25)$;

d. Paling kurang $25 \%$ dari modal dasar harus sudah ditempatkan dan sejumlah $50 \%$ dari modal yang ditempatkan tersebut harus sudah disetor pada saat Perseroan Terbatas didirikan, yaitu pada saat pendiri selesai menandatangani Akta Pendirian di hadapan Notaris (pasal 26);

e. Maksud dan tujuan Perseroan Terbatas tidak boleh bertentangan dengan Undangundang Ketertiban Umum dan Kesusilaan (pasal 2);

f. Tempat kedudukan Perseroan Terbatas harus dalam wilayah Indonesia (Pasal 2);

g. Didirikan dalam jangka waktu tertentu yang ditentukan dalam Anggaran Dasarnya (pasal 6);

h. Modal dasar terdiri dari seluruh nilai nominal saham (pasal 24).

Pasal 8 ayat (2) UUPT memberikan syarat bagi Akta Pendirian Perseroan Terbatas adalah bahwa Akta tersebut tidak boleh memuat :

a. Ketentuan tentang penerimaan bunga tetap atas saham;

b. Ketentuan tentang pemberian keuntungan pribadi kepada pendiri/pihak lain.

Selanjutnya Anisitus Amanat, ada beberapa kemungkinan alasan penolakan pengesahan Perseroan Terbatas oleh Menteri Hukum dan HAM menurut UUPT Tahun 1995 atau dengan kata lain berikut ini adalah syarat-syarat yang harus dipenuhi untuk memperoleh pengesahan Perseroan Terbatas oleh Menteri Hukum dan HAM RI adalah $^{13}$ :

1. Akta Pendirian tidak dibuat oleh Notaris atau dibuat oleh Notaris tetapi tidak menggunakan bahasa Indonesia (pasal 7 ayat 1);

2. Modal dasar Perseroan Terbatas yang dimohonkan pengesahannya tersebut kurang dari 20 juta (pasal 25 ayat 1 );

\footnotetext{
${ }^{13}$ Anisitus Amanat, Pembahasan Undang-Undang Perseroan Terbatas dan Penerapannya dalam Akta Notaris, h. 11
} 
3. Modal dasar yang ditempatkan kurang dari $25 \%$ dan modal yang disetor kurang dari $50 \%$ dari modal yang telah ditempatkan (pasal 26);

4. Nama Perseroan Terbatas yang dimohonkan pengesahannya tersebut mirip atau sama dengan nama Perseroan Terbatas lain yang sudah ada secara sah atau yang lebih dahulu mengajukan permohonan pengesahan ke Departemen Hukum dan HAM RI (pasal 13);

5. Maksud dan tujuan serta kegiatan usaha Perseroan Terbatas bertentangan dengan Undang-Undang Kesusilaan dan Ketertiban Umum (pasal 2 jo pasal 17 ayat 1b);

6. Anggota pendiri Perseroan Terbatas ada yang WNA, kecuali Perseroan Terbatas dalam rangka PMA;

7. Syarat-syarat perjanjian yang diminta;

8. Pasal 1320 BW kurang dipenuhi;

9. Tidak disertai tanda bukti penyetoran nilai nominal harga saham ke kas Perseroan Terbatas sebesar $50 \%$ dari modal yang ditempatkan;

10. Tidak disertai tanda bukti pelunasan pembayaran biaya pengesahan Perseroan Terbatas;

11. Tidak disertai tanda bukti biaya pengumuman Perseroan Terbatas melalui Tambahan Berita Negara RI;

12. Tidak disertai NPWP atas nama Perseroan Terbatas yang dimohonkan pengesahannya.

\section{E. Prosedur Pendirian Perseroan Terbatas}

Bilamana akan mendirikan suatu Perseroan Terbatas, maka pada pendiri menurut Ahmad Yani dan Gunawan Widjaja (1999 :19-23), melakukan perbuatan hukum sebagai yang tersebut di bawah ini :

1. Para pendiri secara bersama atau kuasanya dating di Kantor Notaris untuk meminta dibuatkan Akta Pendirian Perseroan Terbatas. Yang dimaksud Akta Pendirian itu termasuk di dalamnya Anggaran Dasar dari Perseroan Terbatas yang bersangkutan. Anggaran Dasar ini dibuat sendiri oleh para pendiri sebagai hasil musyawarah antara mereka. Kalau pendiri merasa tidak sanggup untuk membuat anggaran dasar tersebut, maka hal itu dapat diserahkan pelaksanaannya kepada 
Notaris yang bersangkutan. ${ }^{14}$

2. Setelah pembuatan Akta Pendirian itu selesai, maka Notaris pembuat Akta Pendirian atau staf dari Notaris tersebut berdasarkan Surat Kuasa mengirimkan Akta tersebut kepada Menteri Hukum dan HAM. Akta Pendirian tersebut juga dapat di bawa sendiri oleh para pendiri secara bersama atau kuasanya mengajukan permohonan tertulis untuk meminta pengesahan dari Menteri Hukum dan HAM yang diketahui oleh Notaris di hadapan siapa Akta Pendirian tersebut dibuat.

3. Sebagai buktinya Notaris yang bersangkutan akan memberikan surat pengantar. Maksud dari pengesahan tersebut adalah sebagai pengawasan preventif yang dilakukan oleh pemerintah, dimana dengan demikian pemerintah dapat mencegah berdirinya suatu Perseroan Terbatas yang tujuannya melanggar hukum, bertentangan dengan kesusilaan dan ketertiban umum. Jika penelitian Akta Pendirian Perseroan Terbatas itu tidak mengalami kesulitan, maka Menteri Hukum dan HAM dalam jangka waktu paling lama 60 (enam puluh) hari setelah diterimanya permohonan pengesahan tersebut, mengeluarkan Surat keputusan Pengesahan Akta Pendirian Perseroan Terbatas yang bersangkutan. Dokumendokumen yang perlu dilampirkan pada Surat Permohonan Pengesahan Perseroan Terbatas ke Menteri Hukum dan HAM antara lain :

a. Akta Pendirian/Anggaran Dasar;

b. NPWP dari Perseroan Terbatas tersebut yang dimohonkan pengesahaannya.

c. Surat Tanda Bukti telah dilunasinya biaya pengesahan Perseroan Terbatas yang biasanya dibayar melalui rekening Departemen Hukum dan HAM RI di Bank BNI 1946 dan Surat tanda Bukti pelunasan Biaya Pengumuman Perseroan Terbatas tersebut melalui Tambahan Berita Negara RI yang juga dibayarkan melalui Kantor Percetakan Negara di Bank BNI 1946.

1. Tanda Bukti Penyetoran sebagian tertentu modal dasar kas Perseroan Terbatas (PT);

2. Surat Tanda Bukti bahwa baik Direksi maupun Komisaris tidak pernah dihukum karena kesalahan mengakibatkan suatu Perseroan Terbatas dinyatakan pailit atau hukum pidana karena merugikan keuangan Negara

\footnotetext{
${ }^{14}$ Suhrawardi K. Lubis, Etika Profesi Hukum (Jakarta: Sinar Grafika, 2002), h. 28
} 
dalam jangka waktu 5 tahun (pasal 79 jo Pasal 96 UUPT). Surat ini mungkin bisa diperoleh dari Pemda C.q. Kelurahan atau Kepala Desa dan bias juga dengan Ketua Pengadilan Negeri tempat kedudukan formal Perseroan Terbatas.

d. Jika Permohonan Pengesahan Perseroan Terbatas dikabulkan Menteri Hukum dan HAM, maka kewajiban Direksi setelah pengesahan tersebut adalah melakukan pendaftaran Akta Pendirian secara lengkap disertai SK Pengesahan dari Departemen Hukum dan HAM dalam jangka waktu 30 hari setelah pengesahan diberikan oleh Menteri Hukum dan HAM (pasal 21 ayat 1a dan Pasal 2 UUPT Tahun 1995). Kewajiban untuk melakukan pendaftaran tersebut dilakukan desuai dan menurut ketentuan Undang-undang No. 3 Tahun 1982 tentang Wajib Daftar Perusahaan. Adapun instansi yang ditugaskan oleh Undang-undang no. 3 Tahun 1982 untuk mendaftarkan Perseroan Terbatas khususnya adalah Kantor wilayah (Kanwil) dan Departemen Perindustrian dan Perdagangan.

Hal-hal yang wajib didaftarkan untuk badan usaha Perseroan Terbatas menurut ketentuan Pasal 1 Undang-undang wajib Daftar perusahaan adalah:

1) Nama Perseroan Terbatas dan merk Perusahaan.

2) Tanggal pendirian dan jangka waktu Perseroan;

3) Kegiatan pokok dan kegiatan usaha lainnya dari Perseroan Terbatas serta izin-izin usaha yang dimiliki;

4) Alamat Perseroan Terbatas pada saat didirikan termasuk perubahannya serta alamat dari seriap Kantor Cabang, Kantor pembantu dan agen serta perwalian Perseroan Terbatas;

5) Keterangan-keterangan yang berhubungan dengan Direksi dan Komisaris Perseroan Terbatas, yang meliputi :

(1) Nama lengkap dan alias-alianya termasuk nama kecil;

(2) Nomor dan Tanda Bukti diri;

(3) Alamat tempat tinggal yang tetap;

(4) Tempat tanggal lahir dan kewarganegaraan;

(5) Tanggal mulai menduduki jabatan; 
(6) Tanda Tangan;

(7) Lain-lain kegiatan usaha dari Direksi maupun Komisaris Perseroan Terbatas.

6) Modal dasar, modal ditempatkan dan modal disetor serta nilai nominal tiap-tiap lembar saham yang dikeluarkan perseroan terbatas;

7) Tanggal mulai kegiatan usaha, tanggal dan nomor pengesahan maupun setiap persetujuan, pelaporan dari perubahan Anggaran Dasar Perseroan Terbatas serta tanggal pengajuan permintaan pendaftaran;

8) Keterangan-keterangan yang berhubungan dengan kepemilikan saham dalam Perseroan Terbatas, yang meliputi :

(1) Nama Lengkap pemilik saham dan alias-aliasnya termasuk nama kecil;

(2) Nomor dan tanda bukti diri;

(3) Alamat tempat tinggal yang tetap;

(4) Tempat tanggal lahir dan kewarganegaraan;

(5) Jumlah saham yang dimiliki;

(6) Jumlah uang yang disetorkan untuk tiap lembar saham yang diambil bagian.

Kewajiban berikutnya dari direksi setelah dilakukannya pendaftaran tersebut di atas adalah mengusahakan agar Perseroan Terbatas yang telah didaftarkan tersebut diumumkan oleh Pemerintah melalui Tambahan Berita Negara di Jakarta dengan melampirkan semua dokumen yang diperlukan untuk urusan Pengesahan dan pendaftaran termasuk SK Pengesahan dari Menteri Hukum dan HAM RI. Pasal 7 ayat (6) jo ayat (1) UUPT menegaskan bahwa Perseroan Terbatas memperoleh status badan hukum setelah Akta Pendiriannya yang telah dibuat Notaris dengan menggunakan bahasa Indonesia dan disahkan oleh Menteri Hukum dan HAM RI. Tetapi Perseroan Terbatas sempurna sebagai badan hukum setelah diumumkan dalam Tambahan Berita Negara RI. ${ }^{15}$

\section{METODE PENELITIAN}

\section{A. Lokasi Penelitian}

Penelitian ini menggunakan pendekatan normative sehingga dengan demikian

${ }^{15}$ R. Soebekti dan R. Tjitrosudibio, Kitab Undang-Undang Hukum Perdata (Jakarta: PT. Pradnya Paramita, 2005), h. 162 
tidak menetapkan lokasi penelitian sebagaimana dengan sebuah penelitian empiris. Penelitian ini menggunakan pendekatan kepustakaan, yakni melakukan kajian referensi dan norma-norma hukum yang berlaku serta menggunakan pendekatan empiris berupa dengan mengadakan wawancara kepada para Notaris.

\section{B. Jenis dan Sumber Data}

Adapun sumber bahan hukum yang penulis gunakan dalam penulisan ini berupa:

\section{Bahan Hukum Primer}

a. Undang-undang No. 3 Tahun 1992

b. Undang-undang No. 1 Tahun 1995

c. Undang-undang No. 30 Tahun 2004

d. PP RI No. 12 Tahun 1998

\section{Bahan Hukum Sekunder}

Penelitian ini dilakukan dengan pendekatan normative, dalam hubungan ini data yang diperoleh dari berbagai sumber berupa referensi-referensi dan dokumendokumen yang terkait serta dari kumpulan peraturan perundang-undangan yang berlaku yang terkait dengan Notaris dan peraturan pendirian Pereroan Terbatas. Adapun data primer yang juga dilakukan berupa dengan mengadakan wawancara dengan beberapa informan, yakni Notaris.

\section{Teknik Pengumpulan Data}

Teknik pengumpulan data yang diterapkan dalam penelitian ini adalah melakukan penelitian kepustakaan dengan megumpulkan data dengan jalan mempelajari literatur dan berbagai referensi yang berkaitan dengan kenotariatan dan Perseroan Terbatas serta peraturan perundang-undangan yang mengatur mengenai alat bukti serta untuk mendukung data sekunder dan mempertajam analisis dalam mengungkap kenyataan selama penelitian berlangsung, maka penuls melakukan pula pengumpulan data dengan cara mengadukan wawancara dengan beberapa orang Notaris di Makassar.

\section{PEMBAHASAN}

\section{A. Kekuatan Hukum Akta Pendirian Suatu Perseroan Terbatas (PT)}

Sebagaimana yang tertuang di dalam Undang-undang Nomor 1 Tahun 1995 tentang perseroan terbatas (PT) menyatakan bahwa sasaran pembangunan jangka 
panjang kedua adalah terciptanya kualitas manusia dan masyarakat Indonesia yang manju dan mandiri dalam suasan tenteram dan sejahtera lahir dan batin, dalam tata kehidupan bangsa Indonesia antara sesama manusia, manusia dengan masyarakat, manusia dengan alam dan lingkungannya serta manusia dengan Tuhan Yang Maha Esa.

Penegasan saat kelahiran perseroan terbatas (PT) sebagai suatu badan hukum sangat penting bukan saja dari segi pertanggungjawaban pengurus, pemegang saham dan perseroan terbatas (PT) tersebut, tetapi juga penting untuk membedakan antara saat suatu perseroan terbatas (PT) berdiri dengan pada saat perseroan terbatas (PT) menjadi suatu badan hukum. Sebelum maupun sesudah pengesahan suatu akta pendirian perseroan terbatas (PT) dapat melakukan hubungan hukum dengan pihak lain. Tetapi jika syarat di atas belum dipenuhi maka akibatnya pertanggungjawaban perseroan terbatas (PT) tersebut dapat mencakup harta kekayaan pribadi pemegang saham perseroan terbatas (PT) tersebut.

Sesuai dengan asas perjanjian, suatu perseroan terbatas (PT) resmi berdiri sejak pada saat akta pendirian ditandatangani para pihak dihadapan seorang Notaris. Akan tetapi perseroan terbatas (PT) yang telah berdiri tersebut belum menjadi suatu badan hukum hingga saat memperoleh pengesahan dari menteri Hukum dan HAM. Sebelum akta pendirian suatu perseroan terbatas (PT) disahkan oleh Menteri Hukum dan HAM maka pengurus perseroan terbatas (PT) tersebut bertindakn atas nama pribadi dan bertanggung jawab atas segala perbuatan hukum serta akibat hukm yang timbul yang dilakukan oleh perseroan terbatas (PT) tersebut.

Status badan hukum perseroan terbatas (PT) diperoleh setelah akta pendirian suatu perseroan terbatas (PT) disahkan oleh menteri Hukum dan HAM, hal ini karena pertimbangan bahwa untuk lahirnya suatu perseroan terbatas (PT) sebagai badan hukum yang merupakan artificial legal person maka perlu adanya pengesahan. Dengan diperolehnya status badan hukum maka perseroan terbatas (PT) tersebut merupakan badan hukum yang berdiri sebagai subjek hukum pemegang saham yang mempunyai tanggung jawab terbatas.

Makna dari hal tersebut adalah bahwa perbuatan yang dilakukan dengan mengatasnamakan perseroan terbatas (PT) harus dipandang sebagai perbuatan yang dilakukan oleh perseroan terbatas (PT) itu sendiri, seakan-akan perseroan terbatas (PT) 
seperti halnya manusia alamiah yang dapat melakukan perbuatan hukum. Sebagai konsekuensi segala tanggung jawab yang timbul dari perbuatan hukum tersebut hanya dapt dibebankan atau dipikul oleh badan hukum itu sendiri.

Dalam praktik seorang notaris harus selalu melihat kartu identitas para pendiri perseroan terbatas (PT) sehingga hal semacam ini tidak akan terjadi, akan tetapi dalam kenyataan tetap dimasukkan sebagai salah satu factor penyebab suatu akta pendirian perseroan terbatas (PT) tidak mempunyai kekuatan hukum.

1. Para penghadap bukan pendiri perseroan terbatas (PT) yang sebenarnya.

Salah satu persyaratan lainnya untuk mendirikan perseroan terbatas (PT) adalah adanya pernyataan kehendak para pendiri tersebut untuk mendirikan perseroan terbatas (PT) yang dituangkan dalam akta pendirian. Akta pendirian harus dibuat seorang Notaris karena Notaris adalah pejabat yang ditunjuk oleh pemerintah untuk membuat suatu akta pendirian perseroan terbatas (PT). Alasan itulah yang mengharuskan para pendiri untuk menghadap kepada Notaris yang telah mereka sepakati bersama.

Pada saat hari yang telah ditentukan mungkin saja salah seorang dari pendiri berhalangan (sakit) atau berhalangan hadir karena suatu hal yang mendadak yang harus segera diselesaikan, pendiri yang tidak dapat hadir tersebut dapat menunjuk orang lain untuk menandatangani akta pendirian mewakili dirinya.

2. para pemegang saham masih ada yang belum menandatangani akta pendirian.

Ada kewajiban bagi setiap pendiri untuk mengambil bagian saham pada saat perseroan terbatas (PT) didirikan. Sama halnya dengan pendiri maka pemegang saham paling sedikit dua orang atau lebih.

Jika perseroan terbatas (PT) itu adalah perusahaan keluarga dimana suami dan isteri bertindak sebagai pihak pendiri maka biasanya pemegang saham adalah anak-anak mereka sendiri. Suatu akta pendirian perseroan terbatas (PT) tidak mempunyai kekuatan hukum apabila pemegang saham tidak semua menandatangani akta pendirian perseroan terbatas (PT) tersebut. 
B. Kekuatan Hukum Akta suatu Perseroan Terbatas (PT) jika Notaris yang membuat Akta Mempunyai Kedudukan dalam Perseroan Terbatas (PT) tersebut

Dalam Pasal 52 Undang-undang No. 30 Tahun 2004 tentang peraturan jabatan Notaris yang menegaskan sebagai berikut :

(1) Notaris tidak diperkenankan membuat akta untuk diri sendiri, isteri/suami atau orang lain yang mempunyai hubungan kekeluargaan dengan Notaris baik karena perkawinan maupun hubungan darah dalam garis keturunan lurus ke bawah dan atau ke atas tanpa pembatasan derajat, serta dalam garis ke samping sampai dengan derajat ketiga, serta menjadi pihak untuk diri sendiri maupun dalam suatu kedudukan ataupun dengan perantaraan kuasa.

(2) Ketentuan sebagaimana di maksud pada ayat (1) tidak berlaku, apabila orang tersebut pada ayat (1) kecuali Notaris sendiri, menjadi penghadap dalam penjualan di muka umum, sepanjang penjualan itu dapat dilakukan dihadapan Notaris, persewaan umum atau pemborongan umum serta menjadi anggota rapat risalahnya di buat oleh Notaris.

(3) Pelanggaran terhadap ketentuan sebagaimana di maksud pada ayat (1) berakibat akta pendirian perseroan terbatas (PT) tersebut hanya mempunyai kekuatan pembuktian sebagai akta dibawah tangan apabila akta itu ditandatangani oleh penghadap, tanpa mengurangi kewajiban Notaris yang membuat akta itu untuk membayar biayanya, ganti rugi dan bunga kepada yang bersangkutan.

Selanjutnya pada Pasal 52 Undang-undang No. 30 tahun 2004 tentang peraturan jabatan Notaris yang menegaskan sebagai berikut :

Notaris tidak diperkenankan membuat akta dimana ia sendiri, isterinya, keluarga sedarah atau semendah dalam garis lurus tanpa pembatasan derajat dan dalam garis ke samping sampai dengan derajat ketiga baik secara pribadi maupun melalui kuasa bertindak sebagai pihak. Larangan ini tidak berlaku dalam hal isteri, keluarga sedarah atau semenda tersebut bertindak sebagai pembeli, penyewa, pengepah, pemborong serta penjamin dalam akta dimana penjualan di muka umum sepanjang penjualan tersebut dapat dilakukan dihadapan Notaris, persewahan, pengepahan serta pemborongan dikonstatir atau sebagai anggota rapat dimana dari apa yang dibicarakan oleh Notaris dibuat berita acaranya. 
Dalam hal ini terjadi pelanggaran maka akta tersebut hanya mempunyai kekuatan hukum sebagai akta dibawah tangan, apabila itu ditandatangani oleh pihak yang hadir dan Notaris di hadapan siapa akta itu dibuat wajib untuk membayar biaya ganti kerugian serta bunga kepada yang berkepentingan.

Di dalam akta Notaris, notaris melakukan peranan sebagai saksi atas kesaksiannya Notaris dalam menjalankan tugasnya hendaknya tidak memihak sesuai dengan isi sumpah jabatannya dimana di antara lain dikatakan, bahwa Notaris akan menjalankan jabatannya dengan sejujur-jujurnya, seksama dan tidak berpihak.

Tindakan berpihak dapat terjadi, apabila di dalam akta Notaris ia sendiri menyatakan (mengkonstatir) keterangan ataupun perbuatan yang diberikan atau dilakukannya sendiri dalam akta tersebut yang dibuat oleh Notaris atas permintaan dari keluarga terdekatnya atau mencantumkan tindakan-tindakan atau keteranganketerangan yang mereka lakukan atau yang diberikan kepada Notaris tersebut.

Dalam hal seperti ini Notaris tidak berwenang untuk memberikan bantuan bagi dirinya sendiri, isterinya serta keluarga terdekatnya seperti yang dimaksud dalam pasal 52 UU No. 30 tahun 2004 tentang peraturan jabatan Notaris tersebut.

Akibat pelanggaran terhadap kekuatan pasal 52 UU No. 30 Tahun 2004 ialah bahwa akta itu hanya mempunyai kekuatan hukum sebagai akta dibawah tangan dimana hal ini berlaku pula untuk akta pendirian suatu perseroan terbatas (PT) para pihak dapat meminta ganti kerugian kepada Notaris yang bersangkutan karena akta pendirian tersebut hanya mempunyai kekuatan sebagai akta dibawah tangan disebabkan atas kelakuan atau kesalahan dari Notaris itu sendiri.

Berdasarkan pasal 54 UU No. 30 tahun 2004 tentang jabatan Notaris yakni seorang Notaris berhak untuk memberikan grosse dari akta Notaris kepada pihak yang berkepentingan atas akta tersebut. Akan tetapi jika akta pendirian suatu perseroan terbatas (PT) hanya mempunyai kekuatan hukum sebagai akta dibawah tangan maka akta pendirian tersebut kehilangan kekuatan eksekutorialnya, akibatnya grosse akta pendirian tersebut tidak dapat digunakan untuk tujuan eksekusi.

Adakalanya suatu perbuatan hukum tidak harus dengan akta Notaris tetapi ada juga sebaliknya, sebagai contoh perjanjian-perjanjian, sewa-menyewa tidak harus dengan akta Notaris tetapi akta pendirian suatu perseroan terbatas (PT) harus dengan 
akta Notaris karena hal itu diwajibkan oleh Undang-Undang Perseroan Terbatas (UUPT) dan hanya Notaris satu-satunya pejabat yang ditunjuk oleh pemerintah sehingga mempunyai; kewenangan membuatkan akta pendirian suatu perseroan terbatas (PT). tetapi jika Notaris yang membuat akta pendirian tersebut telah melanggar peraturan jabatan Notaris, maka akibatnya ialah akta pendirian perseroan terbatas (PT) tersebut hanya mempunyai kekuatan sebagai akta dibawah tangan.

Suatu perbuatan hukum yang dilakukan untuk mendirikan perseroan terbatas (PT) harus dinyatakan dalam bentuk akta Notaris yang mempunyai kekuatan sebagai akta otentik. Sebagai contoh kasus dari pembahasan tersebut adalah sebagai berikut :

Ira Adriana adnan Notaris di Makassar (wawancara tanggal 24 Maret 2006) terpilih menjabat sebagai sekretaris sebuah perseroan terbatas (PT), bersama para pendiri lainnya menghadap kepada seorang Notaris lain untuk membuatkan akta pendirian perseroan terbatas (PT) tersebut.

Jika Notaris yang membuat akta pendirian suatu perseroan terbatas (PT) mempunyai kedudukan dalam perseroan terbatas (PT), maka akta pendirian suatu perseroan terbatas (PT) tersebut hanya mempunyai kekuatan hukum sebagai akta dibawah tangan.

Akta dibawah tangan tidak sah dalam pendirian suatu perseroan terbatas (PT) oleh karena itu dibutuhkan bantuan dari Notaris lain untuk membuatkan akta pendirian untuk perseroan terbatas (PT) tersebut. Dengan kata lain Notaris atas nama pribadi dapat mempunyai kedudukan dalam suatu perseroan terbatas (PT) tetapi walaupun jabatannya sebagai Notaris dia tidak diperkenankan membuatkan akta pendirian perseroan terbatas (PT) tersebut.

Suatu akta pendirian perseroan terbatas (PT) batal demi hukum jika notaris yang membuat akta itu mempunyai kedudukan dalam perseroan terbatas (PT) tersebut oleh karena Notaris yang mempunyai akta pendirian suatu perseroan terbatas (PT) tidak boleh terlibat atau mempunyai kepentingan dalam perseroan terbatas (PT) tersebut.

Jika Notaris yang membuat akta pendirian suatu perseroan terbatas (PT) mempunyai kedudukan dalam perseroan terbatas (PT), maka akta pendirian suatu perseroan terbatas (PT) tersebut hanya mempunyai kekuatan hukum sebagai akta 
dibawah tangan. Adapun tindakan pelanggaran yang dilakukan oleh seorang Notaris terhadap ketentuan sebagaimana dimaksud pada pasal 52 ayat (1) Undang-undang No. 30 Tahun 2004 tentang peraturan jabatan Notaris yang mengakibatkan suatu akta hanya mempunyai kekuatan pembuktian sebagai akta di bawah tangan atau suatu akta menjadi batal demi hukum dapat menjadi alas an bagi pihak yang menderita kerugian untuk menuntut penggantian biaya, ganti rugi dan bungan kepada Notaris.

\section{KESIMPULAN DAN SARAN}

\section{A. Kesimpulan}

Berdasarkan uraian hasil penelitian di atas, maka dapat ditarik beberapa kesimpulan sebagai berikut :

1. Kekuatan hukum suatu perseroan terbatas (PT) didasarkan pada:

a. Akta pendirian perseroan terbatas (PT) telah mendapatkan pengesahan oleh Menteri Hukum dan HAM.

b. Para penghadap tersebut adalah pendiri perseroan terbatas (PT) yang sebenarnya.

c. Para penghadap telah cukup umur dan dianggap cakap dalam melakukan perbuatan hukum.

d. Para pemegang saham telah menandatangani akta pendirian perseroan terbatas (PT) tersebut.

2. Kekuatan hukum suatu akta pendirian perseroan terbatas (PT) jika melibatkan Notaris sebagai pengurus serta pemegang saham dalam sebuah perseroan terbatas (PT) maka akta Notaris tersebut hanya mempunyai kekuatan hukum sebagai akta dibawah tangan, karena Notaris tersebut telah melanggar kode etik yang tercantum dalam peraturan jabatan Notaris serta melanggar Undangundang No. 30 Tahun 2004 tentang Jabatan Notaris serta pada Pasal 20 PJN Perseroan Perbatas (PT).

\section{B. Saran - Saran}

Berdasarkan kesimpulan diatas, direkomendasikan saran-saran sebagai berikut :

1. Diperlukan adanya informasi secara detail dari para Notaris kepada masyarakat sebagai pihak penghadap/pendiri apabila hendak mendirikan suatu perseroan 
terbatas (PT) tentang prosedur pendirian perseroan terbatas (PT) yang telah ditetapkan dalam undang-undang serta sejauhmana kekuatan hukum suatu akta pendirian perseroan terbatas (PT) jika seorang Notaris ikut terlibat dalam perseroan terbatas (PT) tersebut agar akta pendirian perseroan terbatas dapat diperlukan sebagaimana mestinya.

2. Proses pengesahan akta pendirian perseroan terbatas (PT) cukup dilakukan ditingkat provinsi, tidak perlu dilakukan pengiriman ke Departemen Hukum dan HAM Republik Indonesia karena membutuhkan waktu yang lama serta biaya yang tinggi. Adanya kesadaran bagi para Notaris agar kiranya memperhatikan prosedur pembuatan suatu akta pendirian perseroan terbatas (PT) sekaligus mengetahui akibat-akibat hukum yang timbul manakala seorang Notaris yang membuat suatu akta pendirian perseroan terbatas (PT) ikut terlibat sebagai pihak pendiri atau pemegang saham dalam sebuah perseroan terbatas (PT).

\section{DAFTAR PUSTAKA}

Anisitus Amanat, Pembahasan Undang-Undang Perseroan Terbatas dan Penerapannya dalam Akta Notaris, Jakarta: PT Raja Grafindo persada 1997.

GHS Lumbun Tobing, Peraturan Jabatan Notaris, Jakarta: Erlangga 1992.

HR.Otje Salman S dan anton F. Susanti, Teori hokum, Refika aditama, Bandung

J. Suporanto, 2003. Metode Penelitian Hukum dan Statistic, Bandung: PT. Rineka cipta 2004.

J.T.C. Simorangkir, dkk. Kamus Hukum, Jakarta: Sinar Grafika, 2005

Laksamana Mandiri, Undang-undang No. 30 tahun 2004 tentang Jabatan Notaris, Jakarta: CV. Laksana Mandiri, 2005

M. Yahya Harahap, Hukum Acara Perdata, Jakarta: Sinar Grafika, 2005.

R. SoerosoPerbandingan hukum perdata, Jakarta: Sinar grafika 2005

R. Soebekti dan R. Tjitrosudibio, Kitab Undang-Undang Hokum Perdata, Jakarta: PT. Pradnya paramita , 2005

R. Soebekti, Aneka Perjanjian, Bandung: PT. Citra Aditya Bakhti, 1992

Soedikno Mertokusumo, Hukum Acara Perdata Indonesia, Yokyakarta: Liberty. 1998,

Suhrawardi K. Lubis, Etika Profesi Hukum, Jakarta: Sinar Grafika, 2002. 